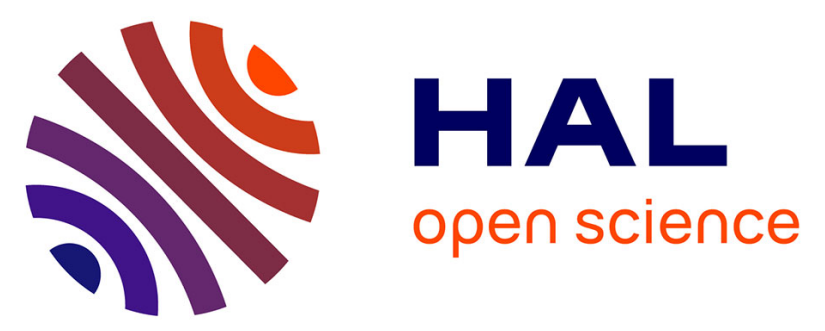

\title{
Comments on the article by Tabache F. et al. "Acute polyarthritis after influenza A H1N1 immunization", Joint Bone Spine, 2011, doi:10.1016/j.jbs.2011.02.007: Primary Sjögren's syndrome occurring after influenza A $\mathrm{H} 1 \mathrm{~N} 1$ vaccine administration.
}

Eric Toussirot, Marie Bossert, Georges Herbein, Philippe Saas

\section{To cite this version:}

Eric Toussirot, Marie Bossert, Georges Herbein, Philippe Saas. Comments on the article by Tabache F. et al. "Acute polyarthritis after influenza A H1N1 immunization", Joint Bone Spine, 2011, doi:10.1016/j.jbs.2011.02.007: Primary Sjögren's syndrome occurring after influenza A H1N1 vaccine administration.. Joint Bone Spine, 2012, 79 (1), pp.107. 10.1016/j.jbspin.2011.09.013 . inserm00799710

\author{
HAL Id: inserm-00799710 \\ https://www.hal.inserm.fr/inserm-00799710
}

Submitted on 7 May 2013

HAL is a multi-disciplinary open access archive for the deposit and dissemination of scientific research documents, whether they are published or not. The documents may come from teaching and research institutions in France or abroad, or from public or private research centers.
L'archive ouverte pluridisciplinaire HAL, est destinée au dépôt et à la diffusion de documents scientifiques de niveau recherche, publiés ou non, émanant des établissements d'enseignement et de recherche français ou étrangers, des laboratoires publics ou privés. 
Correspondence to the article by Tabache F. et al "Acute polyarthritis after influenza A (H1N1 immunization”, Joint Bone Spine, 2011, doi:10.1016/j.jbs.2011.02.007:

\section{Primary Sjögren's syndrome occurring}

\section{after influenza A H1N1 vaccine administration}

Éric Toussirot ${ }^{1,2,3}$, Marie Bossert ${ }^{4}$, Georges Herbein ${ }^{3,5}$, Philippe Saas ${ }^{2,, 6,7,8}$

1- University hospital de Besançon, department of rheumatology, 25000 Besançon, France

2- University hospital de Besançon, CIC Biotherapy-506, 25000 Besançon, France.

3- UPRES EA 4266 «Pathogens and Inflammation», University of FrancheComté, 25000 Besançon, France

4- Department of Rheumatology, Centre Hospitalier, 25200 Montbeliard, France

5- University hospital de Besançon, department of Virology, 25000 Besançon France

6- INSERM UMR645, 1 Bd A Fleming, 25020 Besançon cedex, France

7- Université de Franche-Comté, UMR645, IFR133 25020 Besançon cedex, France

8- EFS Bourgogne Franche-Comté, Plateforme de Bio-monitoring, 25020 Besançon cedex, France.

Corresponding author:Éric Toussirot, department of rheumatology, university hospital Jean Minjoz, 25000 Besançon, France

etoussirot@chu-besancon.fr

Word count : 500 
We read with interest the paper published by Tabacheet al, reporting a case of acute and transient polyarthritis following influenza $A \mathrm{H} 1 \mathrm{H} 1$ vaccination (1). We report here a case of persistent autoimmune disease that developed after the same vaccination.

The patient was a 30-year-old Caucasian woman without medical history. Due to the national $\mathrm{H} 1 \mathrm{~N} 1$ vaccination program in France, she received one dose of Pandemrix ${ }^{\circledR}$ in December 2009. Seven days later, she presented with arthralgia of shoulders, knees, ankles, wrists and fingers. In March 2010, she still had polyarthralgia and reported symptoms of dry mouth and dry eyes. At physical examination, there were tender joints but no joint swelling. Laboratory investigations showed an erythrocyte sedimentation rate of $24 \mathrm{~mm} / \mathrm{h}$, normal C-reactive protein level, positive rheumatoid factors (224 UI/L, nephelometry), positive antinuclear antibodies (1/640, Hep-2 cells), positive antibodies to SSA (211 UI, ELISA), negative anti-citrullinated peptides antibodies, negative SSB and anti-double stranded DNA antibodies. The HLA class II genotyping was: DRB1* 03, ${ }^{*} 15$, DQB1*02, ${ }^{*} 06$. Results from serologic tests for parvovirus $B 19$, Lyme disease, hepatitis $B$ and $C$ virus, human immunodeficiency virus, cytomegalovirus and influenza $A$ and $B$ virus were negative. Shirmer's test was altered and a lip biopsy showed the presence of lymphocytic infiltrates in the salivary glands. A RT-PCR was also performed on the salivary gland tissue and failed to detect the presence of the influenza $A / H 1 N 1$ virus. The patient was treated by hydroxychloroquine giving progressive improvement of arthralgia, but she had still mild and persistent symptoms.

Vaccine has been associated to the development of autoimmune diseases for a long time $(2,3)$ and the vaccination causality is mainly suspected by the temporal relationship between these two events. Different mechanisms may explain these autoimmune phenomena: molecular mimicry, epitope spreading, polyclonal activation and bystander activation (3). Our patient had positive antinuclear antibodies and this may be explained by a quick response of the immune system to the vaccine. Alternatively, she could have had these antibodies before the vaccination due to a dormant autoimmune disease and the injected vaccine had revealed the disease. We did not detect the presence of influenza A H1N1 RNA in the labial tissue using PCR method, leading to the conclusion that there was no direct viral presence within the salivary glands. Since the Pandemrix ${ }^{\circledR}$ adjuvant vaccine did not contain viral genetic 
particles, we can hypothesize that vaccine antigens could activate the immune system, and immune cells secondarily traffick to the glands, leading to the clinical symptoms of sicca syndrome. Our patient had a predisposing genetic background (DRB1* 03, $\left.{ }^{*} 15\right)$ for the development of SS (4). Thus, the vaccine (viral particles and/or the adjuvant or both) (5) may have played a role as a triggering event in this patient with a genetic background for SS. Chronic autoimmune phenomena following vaccine administration (such as influenza $A \mathrm{H} 1 \mathrm{~N} 1$ vaccine) are important to report in order to better understand the responsibility of this vaccine. However, these cases are infrequent and a coincidental event cannot be ruled out.

1- Tabache F, El Kartouti A, Naithou A, Hassikou H, Tarib A, Baaj M et al. Acute polyarthritis after influenza A (H1N1 immunization”, Joint Bone Spine, 2011, doi:10.1016/j.jbs.2011.02.007

2- Balofsky A, Agmon-Levin N, Shoenfeld Y. The new H1N1 and HPV vaccines and old fears. Current OpinRheumatol, 2010; 2: 431-436.

3- Agmon-Levin N, Paz Z, Shoenfeld Y. Vaccines and autoimmunity. Nat Rev Rheumatol, 2009; 5: 648-52.

4- Guggenbuhl P, Jean S, Jego P, Grosbois B, Chalès $G$, Semana G et al. Primary Sjögren'ssyndrome : role of HLA-DRB1*0301 -*1501 heterozygotes. J Rheumatol, $1998 ; 25: 900-5$.

5- Shoenfeld Y, Agmon-Levin N. ASIA - Autoimmune /inflammatory syndrome induced by adjuvants. J Autoimmunity, 2011; 36: 4-8. 